Summer 2014

\title{
Making the Client's Peace: "Privatizing" Peace? Global Law Firms Offering Pro Bono Services in Post-Conflict Settings
}

Cindy Daase

University of Konstanz, cindy.daase@uni-konstanz.de

Follow this and additional works at: https://www.repository.law.indiana.edu/ijgls

Part of the International Law Commons, and the Legal Profession Commons

\section{Recommended Citation}

Daase, Cindy (2014) "Making the Client's Peace: "Privatizing" Peace? Global Law Firms Offering Pro Bono Services in Post-Conflict Settings," Indiana Journal of Global Legal Studies: Vol. 21 : Iss. 2 , Article 2.

Available at: https://www.repository.law.indiana.edu/ijgls/vol21/iss2/2

This Article is brought to you for free and open access by the Law School Journals at Digital Repository @ Maurer Law. It has been accepted for inclusion in Indiana Journal of Global Legal Studies by an authorized editor of Digital Repository @ Maurer Law. For more information, please contact rvaughan@indiana.edu.

\section{$\Psi$}

JEROME HALL LAW LIBRARY

INDIANA UNIVERSITY

Maurer School of Law
Bloomington 


\title{
Making the Client's Peace: "Privatizing" Peace? Global Law Firms Offering Pro Bono Services in Post-Conflict Settings
}

\author{
CINDY DAASE ${ }^{*}$
}

\begin{abstract}
Lawyers of global law firms have begun to take on complex pro bono representations for clients in peace and constitution-building settings. These lawyers, who often cooperate across different offices of a global law firm, are not acting based on an external mandate but pursuant to an attorney-client relationship. The client is the source of authority and the owner of the process; yet, global law firms that serve pro bono clients are also a form of profit-making transnational corporation. In their day-today business they represent the interests of paying clients. This article will discuss whether and how such constellations can lead to power, infrastructure, and knowledge asymmetries between law firms and their often weak pro bono clients in post-conflict settings. Accordingly, it raises and discusses the following questions: Are the legal profession's domestic codes of conduct strong enough to guarantee good professional conduct by global law firms when providing pro bono services in post-conflict settings with weak or temporarily absent local legal profession institutions? Is it desirable to create a transnational code of conduct for lawyers, law firms, and other institutions for providing pro bono legal services in such fragile peace and constitution building settings? By addressing these questions, this article also approaches pro bono services

* Cindy Daase completed her Ph.D. thesis on "The Internationalisation of Peace Agreements between State and Non-State Parties" at the Faculty of Law of the Freie Universität Berlin. From August 2013 to June 2014 she was a Jerome Hall Post-Doctoral Fellow of the Center for Law, Society and Culture and affiliate of the Center for Constitutional Democracy at the Indiana University Maurer School of Law. Currently, she is a senior research fellow with the Department for Political Science and Public Administration of the University of Konstanz in Germany. Earlier versions of this article were presented and discussed as conference papers at the European Society of International Law Research Forum 2013 in Amsterdam, and then at the Law and Society Association Annual Conference "Power, Privilege, and the Pursuit of Justice: Legal Challenges in Precarious Times" (Boston, 2013).
\end{abstract}

Indiana Journal of Global Legal Studies Vol. 21 \#2 (Summer 2014)

(C) Indiana University Maurer School of Law 
of global law firms as an example of how interests of the private sphere of lawyer-client relations and the public sphere of peace and constitution building merge, and how the legal profession's codes of conduct regulate global law firms and their legal professionals' conduct as global agents of "privatized" peace and constitution building efforts.

\section{INTRODUCTION}

This article will focus on global law firms that provide pro bono services in internationalized post-conflict peace and constitution building settings. My analysis builds on my research examining the internationalization and the diverse array of state and nongovernmental actors involved in the negotiation and implementation of peace agreements between state and nonstate parties to end protracted intrastate conflicts after the end of the Cold War. Ever since coming across Maya Steinitz's 2009 article entitled Internationalized Pro-Bono and a New Global Role for Lawyers in the 21st Century: Lessons from Nation-Building in Southern Sudan ${ }^{1}$ I have been thinking about different pressing questions concerning the involvement of the "global legal profession," and, in particular, of global law firms in peace and constitution building processes on a pro bono basis. My article will detail Steinitz's observations, and critically discuss her argumentation by addressing the following questions: Are national-domestic professional codes; underlying practiced ethical principles of the legal profession; and self-regulation tendencies of law firms, individual lawyers, and groups of lawyers firm enough to guarantee a good professional conduct of global law firms when providing pro bono services in post-conflict settings (i.e., where domestic institutions of the legal profession are weakened, ineffective, or temporarily absent due to a protracted intra-state conflict)? Would it be desirable to create a global-transnational code of conduct for lawyers, law firms, and other institutions providing pro bono legal services in such particularly sensitive settings?2 By addressing these questions, this article will also analyze pro bono services of global law firms as an example of how interests of the private and public spheres merge and how the written and unwritten rules of the legal profession's codes of conduct come into

1. Maya Steinitz, Internationalized Pro Bono and a New Global Role for Lawyers in the 21st Century: Lessons from Nation-Building in Southern Sudan, 12 YALE HUM. RTS. \& DEV. L.J. 205 (2009).

2. See, e.g., Bradley W. Wendel, Informal Methods of Enhancing the Accountability of Lawyers, 54 S.C. L. REV. 967, 968 (2003) (asking implicitly for the accountability of lawyers and of the legal profession). 
play to regulate global law firms and their legal professionals' conduct as global agents of "privatized" peace and constitution building.

To enable these critical reflections, I briefly discuss the foundational idea of pro bono services. I will then continue with a critical reflection of what is presented as the "benefits" of international pro bono services and the new global role of lawyers and global law firms. ${ }^{3}$ I then return to the initial analysis by shifting the focus to tendencies of globaltransnational self-regulation and codes of conduct for the global legal profession and, in particular, global law firms setting their own standards for their involvement in peace and constitution building settings.

Against the background of her first-hand experience working as a young attorney with Latham \& Watkins LLP on the initiation of a largescale pro bono project for the nascent Republic of South Sudan in 2004$2006,{ }^{4}$ Steinitz seeks to contextualize and theorize in her article about a (potentially) growing number of complex pro bono projects taken up by global law firms in the area of international rule-of-law development and the necessary forms of regulating this developing practice of involvement. ${ }^{5}$ At the center of Steinitz's analysis are the "benefits" of pro bono services provided by lawyers of global law firms in complex intrastate post-conflict settings, on possible steps to further "maximize" them, and on how to "minimize" the potential downsides of this form of pro bono work. ${ }^{6}$ By emphasizing the strengths and the effective economy of the classical attorney-client relationship, Steinitz's account offers a new perspective on the involvement of (global) legal professionals and global law firms in intrastate post-conflict settings that goes beyond the commonly discussed roles of (international) lawyers as diplomats, mediators, and advisors. ${ }^{7}$ She instead points to the role of global law

3. See generally Steinitz, supra note 1.

4. Id. at 207.

5. Steinitz emphasizes that it was not her intention to advocate for the supremacy of this form of international aid and rule of law development. Her intention would be instead to describe and analyze the nature of pro bono services as a new tool and as one of many mechanisms of international aid. She inter alia finds that:

Whatever one thinks about the desirability of these trends, they are here to stay and are, in fact, likely to expand given the current socioeconomic characteristics of globalization. Therefore, like so many other new phenomena in global affairs, the trend of large international law firms' internationalized pro bono runs up against the problem of the Id. at 214 . global governance gap.

6. Id. at 207-08.

7. The most commonly discussed role of international lawyers is the role of acting in political and administrative offices based on an external mandate given, for instance, by the United Nations, other international and increasingly regional organizations, individual states, and groups of states (i.e., so-called groups of friends or contact groups 
firms that have begun to take on pro bono representations for clients in the transformation from conflict to peace, ${ }^{8}$ such as Lawyers Without Borders; ${ }^{9}$ the Public International Law \& Policy Group (PILPG); ${ }^{10}$ Advocates for International Development (A4ID);11 and international law firms like Latham \& Watkins LLP, ${ }^{2}$ Wilmer Cutler Pickering Hale

that are involved in intra-state conflict and post-conflict settings). See generally Cindy Daase, The Law of the Peacemaker: The Role of Mediators in Peace Negotiations and Lawmaking, 1 CAMBRIDGE J. INT'L \& COMP. L. 107 (2012); Cindy Daase, The United Nations and the Secretary-General as Mediators and Norm-Promoters, Global Norms and Standards in the Mediation of Intra-State Conflicts, in RECHTSANALYSE ALS KULTURFORSCHUNG, VERLAG VITTORIO KLOSTERMANN 267-292 (2012); Teresa Whitfield, Good Offices and "Groups of Friends", in SECrETary OR General, The UN SECRETARYGEneral IN WORLd Politics, 86 (Simon Chesterman ed., 2007); W. Michael Reisman, Stopping Wars and Making Peace: Reflections on the Ideology and Practice of Conflict Termination in Contemporary World Politics, 6 TUL. J. OF INT'L \& COMP. L. 5 (1998).

8. For examples, and about the dimensions of the limited number of large scale and resource-intensive pro bono projects in state and constitution making processes, see Steinitz supra, note 1. See also Brooks Daly, The Abyei Arbitration: Procedural Aspects of an Intra-state Border Arbitration, 23 LEIDEN J. INT'L L. 801 (2010). See generally JOHN Corker, ACCess to Justice - InTernational Pro Bono Legal Assistance: A PAPER FOR THE MEETING OF SENIOR OFFICIALS OF COMMONWEALTH LAW MINISTRIES MARLBOROUGH HOUSE (2010) (describing the trend toward the internationalization of pro bono work).

9. Lawyers Without Borders is a global group of volunteer lawyers from around the world who offer pro bono services to rule of law projects, capacity building and access to justice initiatives. The aim is to bring together pro bono lawyers from large law firms, the private bar, in-house counsel, and non-profit organizations. See LAWYERS WITHOUT BORDERS, http://www.lwob.org/Pages/Default.aspx (last visited Apr. 27, 2013).

10. Since 1995 the PILPG has provided pro bono legal assistance to states and governments involved in peace negotiations, drafting post-conflict constitutions, and prosecuting war criminals. See PUbLic InTERnational LAW \& POLICY GROUP (PILPG), http://publicinternationallawandpolicygroup.org (last visited Apr. 27, 2013). In 1995 PILPG's President and co-founder Paul Williams was, for instance, involved in the peace negotiations for Bosnia and Herzegovina. See RICHARD HolbrooKE, To END A WAR 224 (The Modern Library rev. ed. 1999) for a critical note about Williams' work.

11. A4ID is a U.K.-based international development charity established in 2006 that aims to further the United Nations' Millennium Development Goals. A4ID activities focus on three distinct areas: international pro bono, education, and awareness rising. A4ID inter alia works through development partners including local and international NGOs; inter-governmental organizations; social enterprises, bar associations, and law societies; and developing countries' governments. A4ID receives requests for legal advice and assistance and matches them with lawyers who are able to assist. This includes a wide range of leading law firms and chambers in the United Kingdom (legal partners pay membership fees) as well as in-house legal teams and legal academic institutions. See ADVOCATES FOR INTERNATIONAL DEVELOPMENT (A4ID), http:/la4id.org (last visited Apr. 27,2013 ).

12. See Latham \& Watkins LlP: Pro Bono Practice, (2006), available at http://www.lw.com/upload/pubContent/_pdf/pub2255_1.pdf. 
and Dorr LLP,13 and DLA Piper's global pro bono initiative "New Perimeter," 14 to name just a few. These organizations and law firms are involved in peace, constitution and institution building, and dispute settlement, as well as (transitional) law-making processes on behalf of their clients. They have entered the crowded field of internationalized intrastate peacemaking and building by offering their legal expertise and services pro bono to government leaders of states emerging from conflict and/or emerging new states. ${ }^{15}$ What is puzzling in Steinitz's account, however, is the rhetoric she uses to emphasize-in a rather economic or corporatized language-the "benefits" of the lawyer-client relationship, especially by presenting pro bono services by global law firms as a new and complementary form of client-oriented international rule-of-law development and legal aid. This language begs the question of whether a new phenomenon, a strong corporate sociolegal responsibility aspect of pro bono services in state and constitutionbuilding processes provided by global law firms, emerged?16 Pro bono services by global law firms in post-conflict peace and constitution building processes appear to have two faces: 1) the individual attorneyclient relationship between pro bono lawyer and client as a

13. See Wilmer CUTLER PICKering Hale AND DoRR LLP, http://www.wilmerhale.com; Daly, supra note 8, at 821 (last visited Oct. 1, 2014) (mentioning Wilmer Cutler Pickering Hale and Dorr LLP's involvement - on a paid basis - in the Abyei Arbitration 2008-2009 and the risk of taking up large-scale pro bono projects even for big international law firms). See generally, Wendy J. Miles \& Daisy Mallett, The Abyei Arbitration and the Use of Arbitration to Resolve Inter-State and Intra-State Conflicts, 1 J. INT'L DISPUTE SETTLEMENT 313 (2010).

14. See New Perimeter: DLA PiPer's Global Pro Bono Initiative, http://www.newperimeter.org (last visited Apr. 27, 2013). "New Perimeter" is a non-profit subsidiary international law firm, dedicated exclusively to long-term international pro bono work. An example of New Perimeter's work can be seen in Kosovo. See Kosovo LEGAL PROFESSION, http://www.newperimeter.org/our-work/access-to-justice/kosovo-legalprofession.html (last visited Apr. 30, 2013).

15. Whereas peacemaking could be considered as the process of bringing armed conflict to an end, peacebuilding involves creating a set of conditions where people are not inclined to resort to violence as a means of solving their problems. The lines between these processes as well as between (intra-state) conflict and post-conflict situations are fluid. Furthermore, the expression "emerging new states" is used for cases like South Sudan or Kosovo.

16. See generally Julia Alanen, Pro Bono Across Borders, AM. U. WASH. C.L. 24 (2012), available at http://globaljusticeinitiative.files.wordpress.com/2012/01/alanen-pro-bonoacross-borders-global-network- winter-2012.pdf (discussing global pro bono projects implemented by "mega law firms" as proof of a "socially responsible" form of legal business); Russell G. Pearce, Law Day 2050: Post-Professionalism, Moral Leadership and the Law-as-Business Paradigm, 27 FLA ST. U. L. REV. 9 (1999); DAVD KENNEdY, ThE DARK SIDE OF VIRTUE: REASSESSING INTERNATIONAL HUMANITARIANISM 149 (2004) (discussing on the often implied nexus between economic development and rule of law reform). 
complementary form of international legal aid and rule-of-law development, and 2) the complexities, ambivalences and regulative gaps of pro bono services provided by global law firms, involving individual lawyers in numerous offices working under different jurisdictions across the globe. Offices of global law firms that offer their pro bono services in these complex post-conflict settings are not only altruistic associations of legal professionals, but also profit-oriented entities. ${ }^{17}$ In their day-today business, these lawyers also represent the interests of their regular clients such as globally operating transnational corporations and other solvent states. These concerns make the critical observer wonder whether pro bono services could also carry the risk of a conflict of interest between the firm's business clientele and pro bono clients and even within a law firm's offices and between individual lawyers playing out in the sensitive settings of peace and constitution building. ${ }^{18}$

Moreover, pro bono services by global law firms could be seen as carrying with them inevitable power, infrastructure, and knowledge asymmetries between international lawyers and law firms and their often "weak" pro bono clients. ${ }^{19}$ These pro bono services by global law firms also indicate a strong North-South dimension as the various lawyers and offices who can afford to offer complex international pro bono services will often be and work from a home base in a prosperous and stable country in the Northern hemisphere, while the potential pro bono clients-whose peace and constitution-building process is at stake-will often be in the Global South. ${ }^{20}$

17. International "mega law firms"/global law firms are compared to hospitals who can serve the various needs of their "patients." This includes, for instance, working-hours, infrastructure needed, as well as diverse forms of expertise. See Marc Galanter \& Thomas Palay, Large Law Firms and Professional Responsibility, in LEGAL ETHICS AND PRofessional RESPONSIBILITY 189, 189-202 (Ross Cranston ed., 1996).

18. Ideally, the professional conduct of lawyers and law firms in cases of collisions of interests within a law firm and/or between the regular clientele's and the pro-bono client's interests should be regulated by well-rehearsed procedures and standards of the legal profession.

19. See Sara Kendall, "Constitutional Technicity": Displacing Politics through Expert Knowledge, 9 LAW, CULTURE \& HUMAN. 1, 2-3 (2013).

20. This North-South relation has to be seen as different to the dimensions of the North-South relations explored in cause lawyering. See Austin Sarat \& Stuart A. Scheingold, Cause Lawyering and the Reproduction of Professional Authority, An Introduction, in CAUSE LAWYERING, POLITICAL COMMITMENTS AND PROFESSIONAL RESPONSIBILITIES, 3-28, 20 (Austin Sarat \& Stuart A. Scheingold, eds., 1998); Stephen Ellmann, Cause Lawyering in the Third World, in CAUSE LAWYERING, POLITICAL Commitments AND Professional Responsibilities, 349-430 (Austin Sarat \& Stuart A. Scheingold, eds., 1998). See also Stephen Meili, Latin American Cause-Lawyering Networks, in CaUse Lawyering AND THE STATE IN A GLOBAL ERA, 307-333, 316, 329 (Austin Sarat \& Stuart Scheingold, eds., 2001) (exploring how Latin American 
Altogether, in the outlined post-conflict settings, global law firms and their lawyers become pro bono peace and constitution-building agents that restructure a post-conflict state's foundational law and order, going beyond the classic attorney-client relationship. As a result of their legal advice, this development comes with several potential risks. The outlined pro bono services could introduce and create new forms of governance of peace processes after intrastate conflicts (e.g., those driven by a focus on elites, effectiveness criteria, and the economy of law and politics), and they could create legal solutions that superimpose autochthonous post-conflict transformation, constitution, and law-making processes by offering tailored concepts informed by external normative codes and presumptions. Consequently, new forms of involvement of private actors (i.e., individual lawyers and law firms) in the making of foundational laws in post-conflict situations emerge. They could even gain a particular dominant influence when the client neither has the capacity nor the knowledge to make informed decisions. These concerns made me wonder about potential "dark sides" of global pro bono services that Steinitz does not comprehensively address and elaborate in her article.

\section{The General IdeA of Pro Bono and Its Globalization AND CORPORATIZATION}

It is beyond the scope of this article to give an in-depth and comparative overview about the historical development of the legal profession and the discussions about its ethical values and standards. Instead, I will briefly address the general underlying ideas of domestic pro bono, and then point to its challenges and novelties from a global perspective. I will inter alia discuss what it means when the legal profession and pro bono services are moved to the transnational stage, especially when global law firms, which embody the globalization, localization, and corporatizing of pro bono, offer their pro bono services to actors/clients in complex intrastate post-conflict settings.

The term "pro bono" is commonly used to describe services performed voluntarily by an individual member of the legal profession, without pay, to help people with their legal problems. Often, legal assistance is also provided to public and civil society organizations and charities involved in social causes such as minority rights, women's

transnational cause lawyering networks are most often initiated and funded by the North). 
rights, and education issues as a service to the welfare of the public. ${ }^{21}$ The professional and social responsibility of the individual lawyer to provide pro bono services is traditionally strongly rooted in the respective domestic context, especially among associations of the legal profession. In contrast, pro bono services offered by global law firms often include other factors, such as the internal and outreach advantages of pro bono services for these firms, as well as marketing, reputation, and team-building effects (see infra). ${ }^{22}$

The common understanding is that pro bono work uses the specific skills of legal professionals to provide services to those who are unable to attain and afford them. ${ }^{23}$ This identifiable general understanding of pro bono seems to be closely connected, but not necessarily identical, to altruistic action that can be characterized as selfless concern for the well-being of others, ${ }^{24}$ to philanthropy as the desire to promote the welfare of others, expressed especially by the generous donation of money to good causes, and to humanitarian action or humanitarianism that is concerned with promoting human welfare. ${ }^{25}$ In the case of pro

21. Pro Bono Publico, OXFoRD DiCTIONARY, http://www.oxforddictionaries.com/us/ definition/american_english/pro-bono-publico?q=protbono (last visited June 2, 2014); Jill Anderson \& Gordon Renouf, Legal Services 'for the public good,' 28 ALT. L.J. 13, 14 (2003).

22. Id. at 13-17.

23. Moreover, in the UK, for instance, pro bono publico is also used to describe the central motivation and activities of large organizations and various NGOs, which exist "for the public good," rather than for shareholder profit. Additionally, it is also worth noting that pro bono and legal aid are sometimes clearly distinguished; other times the line between the two is blurred.

24. Pro Bono Publico, supra note 21; See Deborah L. Rhode, Pro Bono in Principle and in Practice, Stan. Pub. L. \& Legal Theory Working Paper No. 66, 2003, for the complexity with which the relation between pro bono and altruism could be discussed:

Although the concept of altruism has generated a rich body of research, that work rarely figures in discussions of lawyers' pro bono activity. Part of the reason may be the daunting scope of material across multiple disciplines, including philosophy, psychology, sociology, and political science, as well as applied work on philanthropy and community service. Extrapolating insights to the legal profession is a challenge, given the volume of potentially relevant research, the diversity in definitions of altruistic behavior, and the range of methodologies for assessing it. The challenge is further complicated by dissimilarities in factual settings between most of the empirical and clinical work on altruism, and lawyers' pro bono activities. Yet despite these complications, many of the research findings on altruism are sufficiently consistent across widely varying contexts to yield insights for the legal profession.

Id. at 3-4.

25. Humanitarian, OXFORD DICTIONARY, http:/www.oxforddictionaries.com/us/ definition/american_english/humanitarian? $q=$ humanitarian (last visited June 2, 2014); see KENNEDY, supra note 16 , for a critical position toward humanitarian activism. 
bono services offered by global law firms, pro bono means investing inhouse resources for providing unpaid legal services to clients. ${ }^{26}$

Questions that remain open are: Who is actually entitled to receive pro bono services? How are pro bono clients and projects selected? Domestic associations' codes usually address these and other questions. ${ }^{27}$ Yet, when it comes to international pro bono services and cross-border lawyering, the International Bar Association (IBA) underlines that there is no universally accepted common definition of pro bono work and services provided by lawyers and, in particular, by global law firms. Rather, every domestic professional association of lawyers will typically have its own definition that can also be considered an expression of the particular legal, cultural, and traditional perception of the legal profession in domestic contexts. ${ }^{28}$

When it comes to global law firms offering pro bono services and the lawyers involved in these pro bono projects, it can be found that they are not acting based on an external mandate, but instead on a traditional client-attorney relationship. The clients are considered the source of authority in this relationship (i.e., they give the mandate and set the agenda and objectives for the attorneys' work on their behalf). Additionally, global law firms-usually from the United States or the United Kingdom-will often have their own in-house concepts and policies for pro bono work that serve as guidelines for their lawyers. ${ }^{29}$ Additionally, of particular relevance in this context is that global law firms' pro bono services will normally also not be attached directly to conditionality criteria and benchmarks, which usually are characteristic of donor-recipient relationships in the course of international donor involvement and legal aid in peace, state, and capacity-building processes. In the global law firm pro bono lawyer-client relationship, the client stays - at first glance - the (sovereign) owner of the process. ${ }^{30}$

26. Philanthropy, OXFORD DiCTIONARY, http://www.oxforddictionaries.com/us/ definition/american_english/philanthropy?q=philanthropy (last visited June 2, 2014).

27. See, e.g., Compilation of Pro Bono Research, INT'L B. Ass'N 1, http://www.internationalprobono.com/resources/folder.235860-Pro_Bono_Definitions (last visited Oct. 1, 2014) (providing information on pro bono research in several countries around the world).

28. Id.

29. The focus of the pro bono concepts and policies are very wide ranging when it comes to particular focuses of activities on the domestic or international level. See, e.g., Commitment and Continuity, WILMERHALE, http://www.wilmerhale.com/probono/\#! ! last visited Oct. 1, 2014); Mission, NEW PERIMETER, http//www.newperimeter.org/about/index.html (last visited May 6, 2013); Pro Bono \& Community Service, Lathams \& WaTkInS LLP, http://www.lw.com/AboutUs/ProBonoAndCommunityService (last visited May 6, 2013).

30. Whether this comparison of pro bono services with international legal aid and rule of law development involvement is in fact strong, and whether the usage of aid and 
Taking up pro bono projects may not only be the expression of an altruistic mind-set or professional responsibility of globally-acting lawyers and law firms to the (global) public, but can, for all intents and purposes, also follow and include commercial interests, as for instance, to explore new markets and to acquire new clients. This leads to the discussion of the advantages of global law firms offering pro bono services in peace and constitution building settings and to the exploration of possible risks and blind spots around the debate of whether and how the global legal profession and pro bono services by global law firms could and/or should be regulated transnationally in post-conflict settings. Again, it must be emphasized that global law firms are private business entities, and the relationship between attorney and client is a private relationship, while the making of peace and constitutions are or should be public affairs of a state and its population. The indicated double image and complex dimensions of the involvement of global law firms in sensitive post-conflict settings raises concerns about the transparency of the processes and the accountability of the pro bono lawyers. These concerns raise, for instance, the question whether, in case effective domestic institutions of the legal profession are weakened or absent in a post-conflict state, the global legal profession should be regulated by local nongovernmental organizations that partner with the pro bono project or clearing house initiatives that take up the tasks of matchmaking, standard setting, and monitoring?

\section{Global LaW Firms OfFering Pro Bono Services in Post-conflict SetTings: MaKing THE Clients' Peace and/OR "Privatizing” Peace?}

I now turn to the potential advantages and disadvantages of the pro bono engagement of global law firms and their lawyers in the transformation from conflict to peace. Undeniably, the analysis faces a problem with sources, which does not allow for the illustration and discussion of single cases of global law firms' involvement on behalf of their pro bono clients. ${ }^{31}$ The available material (reports, statements, analyses) is naturally restricted because information, insights, and details about the relation between lawyers/law firms and their pro bono clients are confidential. ${ }^{32}$ Hence, I use the available material to reflect

development language and perspectives for analysing pro bono involvement fits, will be further critically discussed infra.

31. For instance, we do not learn more from either Steinitz or Latham \& Watkins LLP about the concrete nature of their services performed due to confidentiality rules. Instead, they use placeholders like "advise" and "research." See generally, e.g. LATHAM \& WATKINS LLP, supra note 12; Steinitz, supra note 1.

32. See generally CORKER, supra note 8. 
on the stated motivation and rationality of global law firms for taking up pro bono projects and their conduct, which is closely connected to and a telling indicator of their self-perception, mind-set, bias, and the "socialization" of the individual lawyer. I focus on pro bono concepts and discourses and rhetoric, as well as stated codes of conduct and identifiable tendencies of global-transnational self-regulation. ${ }^{33}$

\section{A. Pro Bono Services by Global Law Firms as a Complementary Form of International Legal Aid and Rule of Law Development?}

Steinitz puts in her article a strong focus on the "benefits" of pro bono services. She finds that, through providing pro bono services, global law firms-so-called mega law firms-have taken on a new role in peace, state, and constitution-building contexts. Steinitz points out, the comprehensive list of "benefits" of pro bono services includes the duty of care and loyalty to which a pro bono client is entitled, ${ }^{34}$ as well as the clear distinction between the attorney-client relationship and the donor and receiver relationship in the international aid and rule-of-law development contexts. The latter is often heavily criticized for creating asymmetries and legal transplants and, in the end, negative effects on the ownership of transformation processes through rigid and inflexible sets of conditions set by the donor. ${ }^{35}$ In the given context, the attorneyclient relationship premise, in contrast, is that the client sets the objective, agenda, the final decision, and that the lawyer provides a service-pro bono-to the client to realize them. Hence, ownership, the "golden standard" of international legal aid and rule-of-law development involvement, would come rather naturally, as it is at the core of the attorney-client relationship. ${ }^{36}$

From this perspective pro bono services by global law firms offer a unique way to ensure local ownership of the process and its content by the client due to the strict requirements of the attorney-client

33. See William Walters, Governmentality: CRitical Encounters 3, 30, 38, 40 (2012) (discussing the idea of governmentality and societal and political change); concerning the importance of motivation for cause lawyering, see Stuart A. Scheingold, Cause Lawyering and Democracy in Transnational Perspective, in CAUSE LAWYERING AND THE STATE IN A GLOBAL ERA 382-405, 393 (2001).

34. Steinitz, supra note 1 , at 215 .

35. Id.

36. See id. at 216,219 (demonstrating further references to codes of the legal profession). According to Steinitz, unlike other actors in the field of international aid and rule of law development, private lawyers and law firms providing pro bono services "do not receive donations, and do not have mandates others than those given/dictated by the client within the bounds of the ethical regulations, and are not accountable to real or imagined constituencies other than the client." Id. at 206. 
relationship (i.e., the professional rationale and social code of the legal profession followed by global law firms). ${ }^{37}$ In peace negotiation and building processes, this leads to the effect, according to Steinitz, that pro bono lawyers adopt their client's position instead of mediating and negotiating a compromise following an external legal or political "mandate," or instead of supporting both sides to avoid suspicion of taking sides, which is common for private diplomacy and mediation but also other legal aid and consultancy services that do not follow the pro bono lawyer-client relationship paradigm. ${ }^{38}$ Hence, pro bono lawyers should focus on maintaining the confidence of their clients, acting independently of any third party, and keeping the authority and ownership in the hands of the client. ${ }^{39}$

Additionally, the network of individual offices of global law firms that are spread across the globe can offer their services and solutions for urgent problems almost 24/7.40 This points to the effective infrastructure of global law firms' office networks and the resources they can potentially mobilize for complex pro bono projects like constitution, law, and institution building and making. It has to be pointed out that large-scale pro bono projects in post-conflict settings are challenging, even herculean projects, even for a network of lawyers and offices of so-called mega law firms with joint extensive human resources and infrastructure. ${ }^{41}$

Furthermore, globally operating law firms can offer a flexible variety of experts; and expert groups with various specializations, social, cultural, and educational backgrounds working under different jurisdictions. Thus, the greatest variety of services of the legal discipline ranging from international to constitutional to commercial, corporate, and trade law are deployed to suit the client's needs. ${ }^{42}$ As a particularly illustrative example of these "benefits," Steinitz points to the expertise of global law firms in dealing with and knowing of the preferences of multinational corporations and international investors. Thus, global law firms offer, so the argument goes, expertise in dealing with transnational business corporations and investors inter alia by creating

37. Id, at 206 .

38. Id. at 219 .

39. Id. at 206,220 .

40. Id. at 223 .

41. For example, concerning the Abyei Arbitration and the SPLM/A, see Daly, supra note 8 , at $822-23$.

42. Galanter \& Palay, supra note 17, at 189-90 (comparing big/mega law firms to hospitals who can offer their "patients" full treatment). 
an investor-friendly, but at the same time restricting, environment for the reconstruction of post-conflict economies. ${ }^{43}$

This presented advantage ties in with the international, global economic development approach, according to which a sustainable peace process is connected to economic and socioeconomic growth. This growth, in turn, also demands a pragmatic foreign investment-friendly legal and liberal market reform, especially in resource-rich conflict and post-conflict settings. Following this rationale indicates an important role of the private sector in socioeconomic reconstruction processes.

In sum, this conduct is not free of risks of abuses or the establishment of legal transplants in weak post-conflict settings because this form of legal support and expertise could leave little space for maneuvering and political discourse during the ongoing transformation process. This draws attention to the responsibility and accountability of global law firms offering large-scale joint pro bono services in peace and constitution building. ${ }^{44}$

These points show interesting commonalities to ongoing debates about activist and cause lawyering whose conceptual borders to pro bono services are fluent. Cause lawyering seeks to reconnect law and morality and to build a good society, while challenging the legal profession's norms of neutrality and client-orientation by viewing clients and their cases as instrumental for pursuing larger social and political

43. Steinitz, supra note 1 , at $222-23$ ("[T] intimate familiarity of attorneys practicing at mega-firms with the inner workings, perspectives and business methods of multinational corporations is invaluable, because multinational corporations are among the most influential players encountered by pro bono clients on the developing world. The training afforded to attorneys who represent oil companies in dealings with governments, for example, allowed for a pragmatic and effective approach to the design of the CPAmandated petroleum commission. Such attorneys understand the interests, concerns, strategies and tactics of oil companies, and how they tend to view government officials in the developing world. The attorneys were able to advise clients on the substance of the law, as well as on negotiation strategies and tactics, based on this understanding."). In Liberia, for example, a group of pro bono lawyers was involved in the re-negotiation of unbeneficial investment and trade agreements with a natural resource focus (mostly timber) during the implementation of the Accra Peace Agreement and under auspices of the Governance and Economic Assistance Program for Liberia (GEMAP). Some big law firms refused to be involved, due to colliding interests with regular clients. See, e.g., Jolyon Ford \& Kyla Tienhaara, Too Little, Too Late? International Oversight of Contract Negotiations in Post-conflict Liberia, 12 CENTRE FOR INT'L GovernANCE \& JUST. 1, 14 (2009).

44. David Bridgman \& Robert Krech, Building Peace Through Investment Climate Reform, in From Civil STRIfe to PEACE Building: Examining Private Sector INVOLVEMENT IN WEST AFRICAN RECONSTRUCTION 248, 261 (Hany Besada ed., 2007); Darren Schemmer, Foreword, in From Crvil STRIFe to PEace BuILding: Examining Private Sector Involvement in West African Reconstruction ix, ix (Hany Besada ed., 2007); see Ford \& Tienhaara, supra note 43 (illustrating the Liberia example). 
goals. ${ }^{45}$ Yet, being driven by a cause also raises the risk of ignoring input from the client and other relevant actors when advocating a cause and overestimating the transformative power of the law over the realities of various interests in post-conflict settings, for instance. ${ }^{46}$ Cause lawyering de-neutralizes and politicizes the understanding of the role of lawyers and raises questions about whose cause is in the center of interest of the lawyer's activities. 47 Serving the client could be considered by the cause lawyer as only one form of serving the cause, next to assumed community interests, and a vision of a good society. ${ }^{48}$ Additionally, cause lawyering will differ across regimes and take different positions toward the democratization project. 49 Sarat and Scheingold find that legal professions need and are threatened by cause lawyering at the same time because this 'moral activism' would put a humane face to lawyering and provide an appealing alternative to the value-neutral role of the lawyer as the client's 'hired gun.'50 Yet, the role of cause lawyering in post-conflict transformation settings, which are at the center of interest in this article, seems unexplored. ${ }^{51}$ The difference from usually discussed forms of cause lawyering is that the above described involvement of global law firms and their lawyers in postconflict settings also includes the involvement in peace and constitution

45. Jayanth Krishnan, Lawyering for a Cause and Experiences from Abroad, 94 CALIF. L. REv. 575, 575-77, 581-83 (2006); Austin Sarat \& Stuart Scheingold, Cause Lawyering and the Reproduction of Professional Authority, An Introduction, in CAUSE LAWYERING, POLITICAL COMMITMENTS AND PROFESSIONAL RESPONSIBILITIES, supra note 20, at 3-28; Austin Sarat \& Stuart Scheingold, State Transformation, Globalization, and the Possibilities of Cause Lawyering, in CAUSE LAWYERING AND THE STATE IN A GLOBAL ERA, supra note 20, at 13 (2001) (finding that cause lawyers choose their clients and cases in order to pursue their own ideological and redistributive projects); moreover, cause lawyering is not connected to a pre-defined ideology; see Austin Sarat \& Stuart Scheingold, The Dynamics of Cause Lawyering, Constraints and Opportunities, in THE Worlds CAUSE LAWYERS MAKE, STRUCTURES AND AGENCY IN LEGAL PRACTICE 17 (2005).

46. From a general perspective on cause lawyering, see Krishnan, supra note 45.

47. See Sarat \& Scheingold (1998), supra note 20.

48. Id.

49. Id.; Sarat \& Scheingold (2005), supra note 45; Stuart Scheingold, Cause Lawyering and Democracy in Transnational Perspective, A Postscript, in CAUSE LAWYERING AND THE STATE IN A GLOBAL ERA, supra note 20, at 382, 392; Scheingold comes to the conclusion: "in an age of sweeping globalization and creeping democratization, just as in the past, cause lawyering is very much a creature of, and contributor to, legal-liberal reforms of democracy. ... [T] he evidence on cause lawyering tends to reinforce the broader record of a liberal-legal homology. This homology can be traced to state structures, to the culture of the legal profession, and to the interaction between them. In other settings cause lawyering is a more precarious enterprise although often able, nevertheless, to make a meaningful contribution to democratic values." Id.

50. Sarat \& Scheingold (2005), supra note 45.

51. Sarat \& Scheingold (2001), supra note 45. 
building (i.e., the making of law and building of entire state structures for the community). ${ }^{52}$ While cause lawyering is rare in corporate law firms, there are clear parallels between pro bono services provided by global law firms and the enhancing idea of corporate responsibility of multinational corporations who take on public or social functions. ${ }^{53}$ Like some of those corporations, global law firms have entered into the "market" of global public peace and constitution building in weak postconflict states, for a long time the terrain of activities of states, intergovernmental organizations, and nongovernmental, nonprofit organizations. ${ }^{54}$

Interestingly, Steinitz dedicates most parts of her article to the enumeration and elaboration of the "benefits" of pro bono services provided specifically by global law firms. ${ }^{55}$ To the impediments and disadvantages she only dedicates three and a half pages, in which she solely mentions these drawbacks and connects them with the question: "How do we maximize the unique benefits conferred by the attorneyclient relationship while minimizing its downsides?"56 Yet, she neither discusses nor comments upon them in particular detail. ${ }^{57}$

Why does a strong proponent of these forms of pro bono not point out the novelty, challenges, and necessity of a simultaneous critique or critical observance of the pro bono engagement of global law firms in sensitive (public) projects like post-conflict lawmaking and state and constitution building? Are there not inscribed risks and potential side effects of implied, dominant knowledge and infrastructure asymmetries and hidden biases and agendas in these attorney-client constellations? Why should pro bono services not be subject to the same critical reflections as international aid and rule-of-law development or publicprivate partnerships in areas of limited statehood? In any case, the almost enthusiastic perspective on the advantages of the alleged clarity of attorney-client relationship raise the question whether the same benefits do not all carry significant risks on the flipside of the coin-the

52. For a general comparison, see Krishnan, supra note 45, although there are examples in which cause lawyers and state actors interact jointly together, and in which cause lawyers develop from opposition to law and institution making, Sarat \& Scheingold (2001), supra note 45 , at 27.

53. Krishnan, supra note 45; Steinitz, supra note 1, at 205. See infra Part II. B (concerning a transnational dimension of corporate responsibility of global law firms as inspiration or role-model for pro bono services with global significance).

54. Id. at 205-06. See infra II. B, for more on the regulative implications of this "trend."

55. Id. at $215-23$.

56. $I d$. at 226 .

57. $I d$. at $223-27$. 
"dark side" of "corporate" pro bono services by global law firms-that need to be considered to enable the benefits to grow stronger. ${ }^{58}$

\section{B. The "Dark Side" of Pro Bono: Blind Spots, Risks, and Potential Side Effects of Pro Bono Services by Global Law Firms in Post-Conflict Settings}

David Kennedy's discussion of a "dark side of (professional) humanitarianism" exposes the blind spots of humanitarians, ${ }^{59}$ e.g., that "humanitarians can get caught by the blind spots and biases of their professional vocabularies and misestimate the costs and benefits of what seems the best policy or activist strategy."60 He contends that humanitarians have to "accept responsibility for the unforeseen and unknowable costs of making our humanitarian visions real in the world,"61 as humanitarians become participants in global governance as "rulers." 62

In a similar vein as Kennedy, this article questions the potential "dark side" of pro bono services by global law firms and their global legal professionals and how these pro bono providers become participants and even dominant actors in governance and policymaking, and of the political economy of peace and constitution building. ${ }^{63}$ Hence, this section puts a particular focus on the risk of a legal, professional dominance that is rooted in the knowledge and power asymmetries between global law firms and their pro bono clients.

To illustrate this with an example: during the negotiation and initial implementation of the Comprehensive Peace Agreement (CPA) between the GoS (Sudan) and the Sudan People's Liberation Movement/Armee (SPLM/(A)), the South Sudanese side had almost no human resources in the form of legal experts or other legal and administrative personnel; no basic institutional, administrative infrastructures (computers, books, copy machines); and also no sufficient financial means to solve these problems quickly. ${ }^{64}$ In short, South Sudan had no effective institutions and structures of the legal

58. See generally KENNEDY, supra note 16 (discussing humanitarian efforts on the global level).

59. Id.

60. Id. at xxiii, 28-29.

61. Id. at xix-xx.

62. Id. at $\mathrm{xx}$.

63. Id. at xviii.

64. See Steinitz, supra note 1, at 209-12 (providing additional details). 
profession on which it could build. This caused an asymmetry between the GoS and SPLM/(A) at the negotiation table and throughout the implementation process of the CPA. The GoS, which had been able to uphold its central state powers and infrastructure, hired legal experts to support it in getting a deal and to start an implementation process that served and suited its strategies and needs. ${ }^{65}$ During the internationalized mediation process, the asymmetric conflict continued at the negotiation table. This also put at risk the goal of the South Sudanese side to build particular constitutional structures and institutions through and after the conclusion of the CPA that would pave the way to South Sudan's independence. In this situation, some lawyers from Latham \& Watkins LLP initiated a large-scale pro bono project for South Sudan/the SPLM/A) that involved lawyers of several offices around the globe.66 This means that Latham \& Watkins LLP provided its pro bono service to the leadership of a party of a peace process, the SPLM/(A), that had been involved in an asymmetric violent intrastate conflict for more than twenty years. ${ }^{67}$ With this service, Latham \& Watkins LLP also supported a leadership and elite-oriented peace process between the main parties to the intrastate violent conflict. ${ }^{88}$ Moreover, Latham \& Watkins LLP's pro bono services did not only serve the interests of its particular client, the SPLM/(A) as such, but pursued and shaped processes which decisively affected the public, constitutional, legal, and political sphere of a post-conflict state. ${ }^{69} \mathrm{In}$ effect, the potential dark side of pro bono in peace and constitution building is revealed through the blind spot of the attorney's ethical

65. Steinitz, supra note 1 , at 209-10. Other authors, however, point to the fragmentation of the legal profession in Sudan. See, e.g. Mark Fathi Massoud, Lawyers and the Disintegration of the Legal Complex in Sudan, in FATES OF POLITICAL LibERALISM In THe British Post-Colony, The Politics of The Legal Complex 193, 209-17 (Terence C. Halliday, Lucien Karpik \& Malcolm M. Feeley eds., 2012).

66. This project had approximately fifty Latham \& Watkins lawyers, working from nine offices around the world like Hamburg, London, and New York. LATHAM \& WATKINS LLP, 2005 PRo BONO ANNUAL REview 5 (2005), available at http://www.lw.com/upload/ pubContent/_pdf/pub1547_1.pdf.

67. Steinitz tends to leave the "A" for army unmentioned in the abbreviation and usually speaks of the SPLM instead of the SPLM/(A). Steinitz, supra note 1, at 207. The SPLM/(A) was party to the CPA and later to the Abyei Arbitration. Id. During the Abyei Arbitration Wilmer Cutler Pickering Hale and Dorr LLP served as council for the SPLM/(A). Id. The costs were covered by Sudan's Unity Fund and the Permanent Court of Arbitration's Assistance Fund. See Daly, supra note 8, at 822-23.

68. See generally Angela M. Banks, Challenging Political Boundaries in Post-Conflict States, J. INT'L L.U. PA. 29, 105 (2007) (explaining the elite-driven process of post-conflict constitution-making).

69. See LATHAM \& WATKINS LLP, supra note 12; Steinitz, supra note 1; supra text accompanying note 31 . 
obligation to be accountable only to the interests of the pro bono clientin this case, the SPLM/(A). This positive point of distinction to conventional external aid and rule-of-law development overlooks voluntarily, or involuntarily, the short-term and long-term risks of this power relationship shaping a post-conflict state's institutions and even its constitution and (transitional) laws. To overlook this contradiction could be a failure to acknowledge the sensitive, multifaceted interactions and overlaps of the private and public sphere in these constellations of foundational lawmaking, as well as the risk of supporting an elite-oriented peace and constitution-building process as the recent outbreaks of massive internal conflicts in South Sudan underline. These outbreaks of conflict can be traced back to the extensive constitutional executive power-monopoly of the SPLM/(A) in the newly independent state that can be traced back to the constitution building process since the CPA.

Other elements which underline my concerns are the knowledge and infrastructure asymmetry between attorney and pro bono client, and the fact that especially large-scale pro bono projects by global law firms cannot only cause collisions of interest between the pro bono client and regular clients of that firm, but also collisions of interests and concepts within the horizontal and vertical structures of the law firm. ${ }^{70}$ It also carries the risk of competing business interests within the law firm and with certain regular paying clients since a law firm is still a business entity. ${ }^{71}$ This leads to the additional risk that, in their mind-set, specialization, and socialization, even with the best intentions, individual lawyers offering their pro bono services in the context of the global law firm's engagement may be too closely related to the internal structure and practice of the law firm and to the set of interests of the usual clients. The lawyers may not be able to fully step outside their working mode that has been developed to serve corporate and other paying clients' interests and that perceive and make law as a business. Corporatization and commercialization of the legal profession may foreshadow how and why pro bono projects are pursued by global law firms in intrastate post-conflict settings to establish a business niche in post-conflict lawmaking. ${ }^{72}$

70. Some big law firms for instance refused to be involved in a pro bono project of treaty renegotiations with foreign investors due to colliding interests with their regular clients in the Liberian peace process after 2003. See Ford \& Tienhaara, supra note 43, at 14.

71. Business conflicts may lead to limiting the scope of a representation, or even to withdrawing altogether. See Steinitz, supra note 1, at 224 n.68.

72. See Anderson \& Renouf, supra note 21 , at 13. 
Global law firms offering pro bono services can also be seen as attempts to fix "global" problems as elite and business affairs by offering their services to governments and other leading actors as part of their corporate professional responsibility. ${ }^{73}$ This "privatization" of external involvement, however, may result in "alienation" of the peace and statebuilding project from sectors of the public/society and a shift to private client-attorney relationships. The dark side of this shift to private relationships causes a legitimacy deficit due to a lack of public discourses about the issues solved through the pro bono services. ${ }^{74}$

In the end, instead of creating a new or complementary form of international rule-of-law development and "legal aid" that is different and creates a counter-balance to international aid and development organizations' involvement and conditionality practice, pro bono services of global law firms have raised the risk of promoting-even despite the intention to act for a good cause-interests of their firm and other clients/parties in post-conflict settings that do not necessarily reflect or meet the variety of local group interests or what is considered to be the public welfare or good of the pro bono client. Moreover, pro bono services-due to the professional mindset and social code of law firms and lawyers working for those law firms-can become a leading example of the political and legal economy of the international aid/development and peace industry. The language Steinitz uses to explain the benefits of international pro bono services in these sensitive transformation settings underlines this concern.

Altogether, it is not my aim to cross-examine pro bono services by global law firms, but to show the pitfalls, double image, and critical risks of pro bono services in post-conflict settings in which effective domestic institutions of the legal profession are weakened or temporarily absent. Thus, pro bono services by global law firms enter with both potentially positive and negative effects into areas of activities previously considered the domain of the (international) public sector aid and development engagement. They add further complexity to the multilayered and multifaceted forms of global public-private governance and lay the groundwork for further private initiatives and roles for private-sector actors in peace and constitution-building

73. Steinitz, supra note 1, at 207; KENNEDY, supra note 16 , at $\mathrm{xx}$.

74. This development can additionally, in the extreme, serve as a cover for forms of neoliberal and legal imperialism in which the ethical obligations/codes, the knowledge and practice as well as which kind of expertise will be provided by "attorneys will become little more than a cover for advancing Western corporate interests," which even Steinitz admits. See Steinitz, supra note 1, at 206, 225. 
processes in states emerging from conflict. ${ }^{75}$ Global law firms enter the sphere of domestic post-conflict transformation processes as part of the international and transnational global governance enterprise in which various forms of external involvement of states, NGOs, international and regional organizations, and private actors like corporations and law firms come together. Another pressing issue remains the question of who are eligible clients for pro bono services in post-conflict settings: governments of emerging new states and governments of states emerging from conflict? Are political factions of armed groups during peace negotiations and peace processes possible clients? Moreover, a tension exists between ensuring that the attorney's services for the client, in fact, serve the public interest, and what could be called the public good, if the-originally private-attorney-client relationship serves the elite/leadership. ${ }^{76}$ This tension highlights an attorney-client model that balances a solution/alternative to international development assistance with legal aid, but it too raises urgent questions concerning cause, form, and effect of the pro bono services in post-conflict peace and constitution-building processes.

Global law firms and individual lawyers who are active on a pro bono basis in state and institution-building processes should pay attention to the question of whom they want to regard as their actual pro bono client. They must consider that the results of peace negotiations, constitution making, lawmaking, and institution-building processes have to be valued by a large portion of the population-the constituency and maybe the actual client ${ }^{77}$-with all potential conflicts about the importation, adaptation, and appropriation of legal solutions and concepts. In the end, the risk that pro bono services may turn out to become, in fact, nothing more than another form and mode of international legal assistance with the strategy to import and transplant constitutional, legal, and political concepts to the client or

75. The public and private sphere (interests) become increasingly blurred, and an erosion of the distinction between public and private sphere (how to regulate this) can be observed.

76. In this context the author finds for instance this statement rather critical: "There is little possibility, outside the attorney-client relationship, for an outcome where the donor strongly disagrees with local priorities but - respecting the role of a sovereign to organize its own affairs - nonetheless provides the requested aid." Steinitz, supra note 1, at 220.

77. This argumentation does not imply that pro bono lawyers could or should be public interest lawyers or take the form of legal empowerment. See generally Maurits Barendrecht, Models of Sustainable Legal Aid: Experiences from NGOs in Five Lower Income Countries (TISCO Working Paper Ser. in Civil Law \& Conflict Resolution Sys. No. 002, 2011); Stephen Golub \& Thomas McInerney eds., Legal Empowerment: Practitioners' Perspectives (Int'l Dev. Law Org., Legal \& Governance Reform: Lessons Learned, No. 2, 2010); Jayanth K. Krishnana, Lawyering for a Cause and Experiences from Abroad, 94 CAL. L. REV. 575 (2006). 
even to create a suitable future client cannot easily be dismissed. ${ }^{78}$ Hence, pro bono services not only serve the client's interest but could also lead to the promotion of a rather instrumentalist model of law and the domestic depolitization and denationalization of peace, constitution and lawmaking in the transformation from conflict to peace..$^{79}$

These are sensitive points that could potentially find constraints through domestic codes of professional conduct, in-house rules for pro bono services by global law firms, and regulations through the home or host state. Yet, these potential constraints can also be seen as potential tensions and collisions between professional codes and standards of individual lawyers, offices, and overarching structures of global law firms that can hardly be viewed as monolithic actors. Hence, these concerns lead to the question of whether there is a need, and first tendencies, to create globalized or transnationalized codes of conduct for the global legal profession and international pro bono services in the particularly sensitive context of post-conflict settings.

\section{TOWARD a Global and TRANSNational (SELF-)REgUlation OF PRO BONO SERVICES?}

An interplay between the domestic and global-transnational regulation of the conduct of the global legal profession and, in particular, on the corporate social-legal responsibility of global law firms seems to exist. A self-reinforcing culture of corporate transnational community involvement in which hybrid forms of regulation of the (global) legal profession and global law firms-almost a public-private code of conduct-and the role of clearing houses initiatives and matchmakers balance each other. This indicates a developing understanding of the legal and political opportunities and constraints of pro bono services in post-conflict settings.

I consider the attempts and tendencies of the transnational selfregulation of the global legal profession and global law firms, as well as established domestic rules and codes of conduct, to be forms of developing a body of transnational law that addresses regulative

78. These "transplants" can inter alia include a set of widely promoted seemingly positive concepts like democratization and the establishment of a liberal market economy (i.e., legal advice and knowledge how to support market oriented legal reforms and institutions). See Jaques Delisle, Lex Americana?: United States Legal Assistance, American Models, And Legal Change in the Post-Communist World and Beyond, 20 U. PA. J. INT'L ECON. L. 179, 183-84 (1999).

79. See, e.g., Megan J. Ballard, Post-Conflict Property Restitution: Flawed Legal and Theoretical Foundations, 28 BERKELEY J. INT'L L. 462, $462-73$ (2010); KENNEDY, supra note 16, at 150-67; Kendall, supra note 19, at 1-15. 
problems that are neither wholly domestic nor comprehensively global (i.e., problems that are sometimes addressed through domestic law and sometimes demand the creation of new institutions). ${ }^{80}$ Alfred Aman contends that the idea of transnational law can include different modes of self-regulation.81 Transnational law may involve domestic law, international law, some form of voluntary regulations, or various combinations of all three. ${ }^{82}$ Transnational law increasingly also involves hybrid forms of power sharing among public and private actors and could, in this particular context, offer room for considering the role of matchmaking institutions and in-country NGOs who set standards and constraints but who also function as an interpreter between the client and the pro bono lawyers who work from different offices across the globe. 83

Voluntary self-regulation, from this perspective, becomes one of the main ways in which law develops outside of the state-domestic sphere (i.e., various law and norm-creating processes may develop among private actors as, for instance, global law firms and representatives of the global legal profession). ${ }^{84}$ In this context, private entities, like global law firms operate simultaneously in multiple jurisdictions within and across national boundaries, as well as between public and private sectors. These global firms create self-regulations and accountability they believe are necessary to govern their activities and transactions in complex transitional situations. ${ }^{85}$ These developments towards selfregulation do not only include formal legal rules and sanctions. For

80. Alfred Aman, Globalization: Legal Aspects, in INTERNATIONAL ENCYCLOPEDIA of THE Social \& Behavioral ScIEnces (Neil Smelser \& Paul Baltes, eds. forthcoming 2014). From a cause lawyering perspective, Sarat and Scheingold find that cause lawyers choose to form and work in transnational networks, i.e. to invest their social capital in the creation of such a network, if it enhances their social capital, and that this is also influenced by external developments at the international/global level. Sarat \& Scheingold (2001), supra note 45. See also Stephen Meili, Latin American Cause-Lawyering Networks, in Cause Lawyering and the State in a Global Era 307-33 (2001).

81. Aman, supra note 80.

82. Id.

83. Id.

84. Id.

85. Id.; Today, various and multilayered codes of conduct govern the legal profession. To discuss them comprehensively goes beyond the scope of this article. For example, national codes of conduct of major associations of legal professionals, codes of conduct of various international judicial bodies. Mark S. Ellis, Developing a Global Program for Enhancing Accountability: Key Ethical Tenets for the Legal Profession in the 21st Century, 54 S.C. L. REV. 1011, 1012 (2003). The IBA Code of Ethics provides guidelines for lawyers who appear before international tribunals. Id. at 1013, n.3. While the UN Principles on the Role of Lawyers is not a code of ethics per se, the UN Principles are included to promote minimum ethical standards of international law governing the legal profession. Id. 
example, conduct that is considered unethical is often regulated by informal, nonlegal code and sanction mechanisms (i.e., penalties imposed by lawyers on each other). The backstop or "the key . . is the value of a lawyer's reputation." 86

Mark Ellis, Executive Director of the International Bar Association, found, already a decade ago, that:

[T] he idea of developing a global program for enhancing accountability through an internationally accepted code of ethics is both appealing and challenging. Whether such an effort would be manifested in an "internationally accepted code of ethics" or reflected general standards that are voluntarily adopted by practicing lawyers, the opportunity to draft such a global accountability standard is ripe. ${ }^{87}$

This "ripeness" is supported by other authors who point to the ethical engagement in a transnational practice, 88 connected to the trend toward discussing global law schools, global legal education, the global legal profession, and what makes the global lawyer and their global practice-in multijurisdictional contexts-in global law firms. ${ }^{89}$ Other voices emphasize that next to the most important role of lawyers and law firms-to represent clients-"other roles include participation in the self-regulation of the legal profession, participation in developing the profession's core values, participation as a public citizen, and participation in interpreting and developing the social compact between the legal profession and society."90 This also underlines that the globaltransnational level can only compliment the domestic level and that rules and standards of global law firms are connected to host states and

86. W. Bradley Wendel, Informal Methods of Enhancing the Accountability of Lawyers for Unprofessional Conduct, 54 S.C. L. REv. 967,970 (2003).

87. And he continued: "There are already common areas of ethical conduct that are fundamental to the legal profession. However, on a closer look there are key tenets that are not universal to all jurisdictions, but which should be. By incorporating these two groups, the legal community can form a solid code of ethics that would promote accountability to its members." Ellis, supra note 85, at 1026.

88. See Ronald A. Brand, Uni-State Lawyers and Multinational Practice: Dealing with International, Transnational and Foreign Law, 34 VAND. J. TRANSNAT'L L. 1135, 1135 (2001).

89. See id. at 1136-37, 1155. Carroll finds: "practitioners and their firms emphasize the global nature of their legal practice, implicitly de-emphasizing the importance of geographic boundaries or, for that matter, the related legal systems." Wayne J. Carroll, Innocent Abroad: Opportunities and Challenges for the International Legal Adviser, 34 VAND. J. TRANSNAT'L L. 34 1097, 1104 (2001). See also id. at 1099.

90. L. Harold Levinson, Foreword, 34 VAND. J. TRANSNAT'L L. 897, 898 (2001). 
to the question of how an individual global law firm is structured (e.g., as joint-venture or single entity)..$^{91}$

Finally, the self-regulation of global law firms and the pro bono services they offer could be compared to the increasing responsibility of corporations toward their direct and indirect stakeholders, which are often addressed through strategic partnerships. ${ }^{92}$ From this perspective, forms of self-regulations are inter alia codes of conduct, mission statements, social-auditing schemes, and global-reporting initiatives. ${ }^{93}$

Another perspective that can inform this discussion about the selfregulation of global law firms, the global legal profession, and the pro bono services they provide in post-conflict settings is to approach the global legal profession of global law firms as an "epistemic community," (i.e., as a network of professionals with shared values with recognized expertise and competence in a particular domain and an authoritative claim to policy-relevant knowledge within the domain or issue-area)..$^{94}$

91. Levinson holds that "[a]lthough a global law firm may not participate in the profession's self-regulation to the extent that law firms of the host country participate, a global law firm may participate with other foreign law firms, or with associations of global firms, in limited types of self-regulation in the host country." See id., at 899. See also id. at 901,904 (noting that a global law firm is not a single entity, it can perform several roles such as joint ventures with local resident partner, giving it a local role under local rules). Last but not least, the self-regulation of global law firms and the pro bono services offered by them could be compared to the increasing responsibility of corporations towards their direct and indirect stakeholders; which are often addressed through strategic partnerships. From this perspective, forms of self-regulations are inter alia codes of conduct, mission statements, social auditing schemes, and global reporting initiatives. See Alyson Warhurst, Future roles of business in society: the expanding boundaries of corporate responsibility and a compelling case for partnership, 37 FUTURE 151, 165 (2005). Concerning corporate social responsibility, see also Ronen Shamir, Between SelfRegulation and the Alien Tort Claims: On the Contested Concept of Corporate Social Responsibility, 4 L. \& SoC'Y REv. 635 (2004).

92. See Warhurst, supra note 91 , at 151, 165; see also Meili, supra note 80.

93. Shamir, supra note 91 , at 635,645 .

94. Peter M. Haas, Introduction: Epistemic Communities and International Policy Coordination, 46 INT'L ORG. 1, 4, 15 (1992). Haas characterizes an epistemic community as follows:

Although an epistemic community may consist of professionals from a variety of disciplines and backgrounds, they have (1) a shared set of normative and principled beliefs, which provide a value-based rationale for the social action of community members; (2) shared causal beliefs, which are derived from their analysis of practices leading or contributing to a central set of problems in their domain and which then serve as the basis for elucidating the multiple linkages between possible policy actions and desired outcomes; (3) shared notions of validity - that is, intersubjective, internally defined criteria for weighing and validating knowledge in the domain of their expertise; and (4) a common policy enterprise that is, a set of common practices associated with a set of problems to which their professional 
According to Peter Haas, "[a]n epistemic community's ethical standards arise from its principled approach to the issue at hand, rather than from a professional code. Unlike members of a profession or discipline, who seldom limit themselves to work that is closely congruent with their principled values, members of an epistemic community tend to pursue activities that closely reflect the community's principled beliefs . . . "95 Indeed, the advantages of pro bono services of global law firms and their (global) legal professionals seem to be based on a strong belief in the professional ideology or the ideology of professionalism of the legal profession. ${ }^{96}$

Lawyers are usually accountable to their domestic bar association and operate under country-specific professional and ethical rules. The individual lawyers who are involved in a global pro bono project can be considered to be bound to the domestic code, especially as global law firms' lawyers involved in global pro bono projects will not necessarily leave their home office's desk to provide their services to a post-conflict client. ${ }^{97}$ However, the particular forms and varieties in which pro bono services are provided by individual lawyers and law firms in intrastate conflict and post-conflict settings underline the necessity of discussing whether traditional, domestic forms of professional codes of conduct are sufficient, appropriate, and relevant to cover global-transnational legitimacy and accountability concerns. ${ }^{98}$

While pro bono services of global law firms and their lawyers in intrastate conflict and post-conflict settings were initially assumed to close a "governance gap," it is the double image of their mission, their

\footnotetext{
competence is directed, presumably out of the conviction that human welfare will be enhanced as a consequence.

Id. at 3.

95. $I d$. at 19.

96. See Richard J. Maiman, The Future of Legal Professionalism in Practice, 2 LEGAL EтHICS 71, 71 (1999).

97. Steinitz, supra note 1 , at 221 .

98. Steinitz argues "that the new theoretical paradigm of Global Administrative Law, a branch of global governance studies, can provide a framework for any future efforts to foster regulation on international pro bono representation." Steintz, supra note 1, at 225. Steinitz takes a Global Administrative Law (GAL) perspective on the self-regulative and network-oriented tendencies of global pro bono services, which does not convince the author at this point. Many authors have addressed GAL. See generally Benedict Kingsbury et al., The Emergence of Global Administrative Law, 68 LAW \& CoNTEMP. PROBS. 15 (2005) (describing how globalized interdependence leads to the increase of transgovernmental regulation); Nico Krisch, The Pluralism of Global Administrative Law, 17 EUR. J. INT'L L. 247 (2006) (pointing to the accountability problems of global governance); Carol Harlow, Global Administrative Law: The Quest for Principles and Values, 17 EUR. J. INT'L L. 187 (2006) (examining whether GAL is desirable); Susan Marks, Naming Global Administrative Law, 37 INT'L L. \& POL. 995 (2005) (suggesting that the naming of GAL has an effect on research).
} 
activities and conduct that, in fact, does not only challenge perspectives on pro bono services by the (global) legal profession, but also creates a transnational governance problem in the context of the internationalization of interstate conflicts (i.e., the need to identify and address local needs and the lack of effective local structures to respond to and set standards and constraints for external actors). Thus, are there emerging professional networks and codes of conduct for international pro bono services of international lawyers, law firms, and other organizations? Pro bono rule-of-law development initiatives around the world have become increasingly visible and relevant. The American Bar Association (ABA) has recently consolidated its rule of law pro bono initiatives, many of which are carried out in cooperation with practitioners and law firms, under the ABA Rule of Law Initiative.99 In 2009, the IBA launched a website dedicated to international pro bono information and coordination. ${ }^{100}$ The website provides resources on pro bono work, such as guidelines, projects, and training materials. It also offers news and regular updates of what other professionals are doing both internationally and locally, as well as an extensive directory of links to various pro bono websites and possible matchmakings. In addition to this, the website also contains a full set of declarations and definitions of pro bono services from various jurisdictions. ${ }^{101}$ Together, this push at ABA/IBA level demonstrates an emphasis towards self-regulation of the global acting legal profession to adapt to global challenges, also in peace and constitution-building settings.

Yet, it fails to actively address the double image of global law firms between professional practice and professional ideology, on the one hand, and the globalization and commercialization of law practice and its possible effect on pro bono services in the outlined post-conflict setting, on the other. Considering that global law firms, in particular, have the capacity to organize large-scale pro bono projects in emerging states and states emerging from conflict, this creates a new internationalized and globalized space for the institutionalization of pro bono work. ${ }^{102}$ The double image is fueled by institutional statements

99. Steintz, supra note 1, at 205, 212, n.30; American Bar Association, RULE of LAW INITIATIVE, http://www.americanbar.org/advocacy/rule_of_law.html (last visited Feb. 6, 2014, 10:00 AM).

100. INT'L BAR ASS'N, http://www.internationalprobono.com (last visited July 19, 2014).

101. Pro Bono Definitions Compilation, supra note 24. The IBA also drafted the IBA Pro Bono Declaration, 16 October 2008, approved by the IBA Council. See CoRKER, supra note 8 , at 2 (proviäing additional examples).

102. See MARC Galanter \& ThOMAS PaLAY, Large Law Firms and Professional Responsibility: The Double Image of the Large Law Firm, in LEGAL ETHICS AND 
such as Pro Bono Across Borders, which points out that "in today's global economy, savvy legal professionals understand the business benefits of doing global pro bono work: acquiring cultural competencies and enhancing international business communication skills, fulfilling social, ethical and professional obligations, showcasing core competencies and making inroads into emerging markets . ..."103 Global pro bono services do not only support human rights or social welfare promotion and other international laws and standards, but these services are also a means to explore new and emerging markets, stimulating the global harmonization and regulation of issues. One might question whether global pro bono services offered by global law firms have been transformed into a new form of "mixed-motive altruism"-a socially responsible business-in sensitive intrastate postconflict settings. ${ }^{104}$

Furthermore, organizations like the Association of Pro Bono Counsels in the United States prove that there is an increasing tendency to professionalize the pro bono management and coordination in global law firms. Like in corporate social responsibility initiatives, the pro bono counsel is responsible for the selection of projects, risk management, team management, screening, and partnerships with other organizations. This increasing degree of institutionalization of pro bono services within law firms goes hand-in-hand with a shift from altruistic and individualized forms to more bureaucratic departmentalized forms of the selection and implementation of pro bono services and projects. This development raises questions about an emerging international law firm (business) culture that creates and sustains pro bono projects. To take up large-scale pro bono projects could become part of the socialization of lawyers and (business) cultures of mega law firms and a particular form of business' social and professional responsibility strategy. ${ }^{105}$

Professional RESPONSIBILITY 189, 199 (Cranston, Ross ed., 1996). See also Pearce, supra note 16 , at 9 (discussing the moral benefits of pro bono).

103. Alanen, supra note 16, at 24.

104. Pro bono and mixed-motive-altruism/pro bono as the virtue of altruism - linkage of altruism and (ideal) professionalism in this field. See Pearce, supra note 16 (advocating for moral leadership of the legal profession); Anderson \& Renouf, supra note 21, at 13; Andrew Boon \& Avis Whyte, "Charity and Beating Begins at Home": The Aetiology of the New Culture of Pro Bono Publico, 2 Legal ETHICs 169, 170 (1999).

105. For much of legal history, pro bono was ad hoc and individualized, dispensed informally as professional charity, but it has become centralized and streamlined, distributed through institutional structures by private lawyers acting out of a professional duty. Pro bono's institutionalization has depended critically on the rise of the large corporate law firm. Although small-scale practitioners have been important actors in the pro bono system, it has been the large firms that have provided the resources and prestige to promote pro bono as a central professional goal. In addition, because large firms are 
Although it is tempting to call for evermore global standards and regulations, caution should be adopted to question how an effective means of regulation of transnational legal practice can be created that takes into account the difficulty of transferring strong domestic codes to the transnational-global level. While international pro bono work is generally considered to be legal work that is focused outside of the country where the globally acting lawyer or law firm is based, much of the legal work is carried out in the country where the lawyer is based. Hence, domestic codes of the legal profession can still be considered to be at the core of the legal profession's socialization and as a way of preserving certain professional traditions and cultures of how individual lawyers operate. The feasibility and extent-and some authors even say the desirability - of a global harmonization is debatable, as its nature is inherently hybrid and multifaceted. ${ }^{106}$ However, there are tendencies toward voluntary transnational self-regulation, which should not be considered as tendencies of "harmonization," but rather as expressions of the emergence of new ideas about the new roles of networks of the global legal profession and law firms. ${ }^{107}$ In the end, the good faith in the professional code and socialization of the individual professional's capacity for self-regulation-and the attorney-client relationshipraises awareness about the social responsibility of lawyers and the necessity of keeping standards of the profession like diligence, courtesy, and fairness to balance the attorney-client relationship.

Finally, locally and transnationally active civil society organizations like clearing house initiatives-NGOs operating as proxies and matchmaker between potential clients and pro bono providers-NGOs like the International Senior Lawyers Project, ${ }^{108}$ or Lawyers Without

highly leveraged, they can generally absorb the costs associated with pro bono more readily than their smaller counterparts. Large firms play a leadership role within the pro bono field. This is discussed from a domestic and international perspective. See Steven Boutcher, Rethinking Culture: Organized Pro Bono and the External Sources of Law Firm Culture, 8 U. ST. THOMaS L.J. 108, 108, n.3 (2011). There is a domestic dimension of pro bono management. See Scott Cummings, Deborah Rhode, Managing Pro Bono: Doing Well by Doing Better, 78 FordhaM L. REV. 2357, 2359 (2010). See also Pearce, supra note 16, at 20; Anderson \& Renouf, supra note 21, at 14.

106. See Steinitz, supra note 1, at 226 ("However, as the growing body of literature regarding the general topic of cross-border lawyering suggests, non-domestic regulation of lawyering must overcome a two-pronged objection: for one, that such regulation cannot be achieved; for another, that it should not be achieved.").

107. See H.W. Arthurs, A Global Code of Legal Ethics for the Transnational Legal Field, 1 LEGAL ETHICS 59, 65 (1999) (arguing that globalization leads to the need for a global code of ethics for lawyers).

108. INTERNATIONAL SENIOR LAWYERS PROJECT, http://www.islp.org (last visited Oct. 1, 2014) ("ISLP provides the pro bono services of highly skilled and experienced lawyers to 
Borders, ${ }^{109}$ as well as nonbusiness pro bono law firms, ${ }^{110}$ have the potential to serve as informal civil society gatekeepers, standard setters, and norm-promoters. ${ }^{111}$ These proxies could underline that the idea of a transnational self-regulation of pro bono services in post-conflict settings can be aligned with expertise in local norms, customs, and cultures. Taking the particular example of South Sudan, Latham \& Watkins, for instance, could not partner with a local law firm or enter into a joint venture with local lawyers as most institutions and structures of the legal profession were shattered by twenty years of civil war. Instead, Latham \& Watkins lawyers partnered with an in-country NGO that had expertise and was trusted on the ground and that was supposed to operate as interpreter between the client and the pro bono lawyers.

\section{CONCLUSION}

Do pro bono services provided by global law firms make the client's peace or could it lead to a privatization and marketization of lawmaking, peace, state, institution, and constitution building? The answer, for the moment, is that it has great potential to make the client's peace in certain issue-areas as a form of complementary privatepublic partnership in the area of legal aid and rule-of-law development. As shown above, there are strong advantages but also aspects of pro bono services provided by global law firms that deserve constant critical self-reflection. It is the simultaneous critical reflection on the blind spots, double image, and potential dark side effects that need particular attention and constant reflection rather than focusing on praising and optimizing the "benefits" of pro bono services by global law firms.

This article also explored the move toward forms of transnational self-regulations of the global legal profession and global law firms when

promote human rights, equitable and sustainable economic development and the rule of law world").

109. See Steinitz, supra note 1, at 212 n.32.

110. The PILPG provides free legal assistance to state and governments involved in peace negotiations, drafting processes, constitution building projects and prosecuting war criminals, they also offer policy advice and training on conflict resolution and peace agreement training session. Paul R. Williams et al., Peace Agreement Drafting Guide: Dafur 2 (Jul. 25, 2008) (Pub. Int'l Law \& Policy Grp., 2007), available at http://papers.ssrn.com/sol3/papers.cfm?abstract_id=1078714. The PILGP which also operates with pro bono law firms project has itself around 60 pro bono legal advisors usually retired from foreign service, mostly international lawyers, who work from the distance or on the ground. Id. Altogether, according to its own statistic PILGP is generating $\$ 10$ Million worth of pro bono assistance, see for instance. Id.

111. See Steinitz, supra note 1, at 212 n.26. 
it comes to pro bono services that complement existing and traditionally strong codes of conduct, ethical standards, and rules of domestic associations of the legal profession. It points to the development of a hybrid regulation of pro bono services provided by global law firms and their lawyers working in various fields and under different jurisdictions in offices around the globe. It also found that large-scale pro bono initiatives in post-conflict settings by global law firms can be considered as a variation of global professional responsibility initiatives in which the pro bono sections of law firms function similarly to corporate responsibility programs of transnational corporations. The question of whether this will eventually lead to a professional and social "culture" of (corporate) pro bono services by global law firms remains to be seen.

At the close of this article, the phenomenon of the transnationalization of peace and constitution-building has emerged and revealed a new dimension of a global peace and constitution building market. Further research is required to investigate the emerging public-private networks and partnership of pro bono projects between lawyers, law firms, clearinghouse or matchmaking initiatives, NGOs, and international aid and rule-of-law development organizations. 